\title{
LIST OF PUBLISHED PAPERS ON TERRES- TRIAL MAGNETISM AND METEOR- OLOGY BY THE LATE CHARLES CHAMBERS, F. R. S.
}

COMPILED BY Professor N. A. Moos, Director of Government OBSERVATORY, COLÁBA, BOMBAY, AND BY L. A. BAUER.

A.-PAPERS Discussed aNd Published under THe AUThority of GovERNMENT.

On the solar variations of magnetic declination at Bombay. Phil. Trans., I869, pp. $363-386$.

The absolute direction and intensity of the earth's magnetic force at Bombay. Phil. Trans., 1872, pp. 75-9o.

The normal winds of Bombay. Appendix I to Bombay Magnetical and Meteorological Observations, I865-70, pp. I99-212, Bombay, I872.

On the lunar variations of magnetic decliuation at Bombay. Appendix III to Bombay Magnetical and Meteorological Observations, I865-70, pp. 235-242, Bombay, 1872 .

Meteorology of the Bombay Presidency. I vol. $4^{\circ}, \mathrm{pp}$. I to 295 , and I portfolio of 82 diagrams, etc. Eyre and Spottiswoode, London, I878.

Notes on a comparison of two unifilar magnetometers, and on magnetic induction as affecting observations of the intensity of the horizontal magnetic force. Appendix to Bombay Magnetical and Meteorological Observations, I87I-78, pp. [53]-[6o], Bombay, I88I.

Bombay Magnetical and Meteorological Observations, I864 to I894. Introductions and Compilations, I4 vols. $4^{\circ}$, Boubay, $1867-1895$.

Appendices to Bombay Magnetical and Meteorological Observations, I879-82, I vol. $4^{\circ}$.

I. History of the set of magnetographs established at the Colába Observatory, with a new theory of the vertical force magnetometer, pp. [I] to [83].

II. On the solar and lunar variations of magnetic declination at Bombay in the years $1846-1872, \mathrm{pp}$. [84] to [137].

III. On the solar and lunar variations of the earth's magnetic force at Bombay in the years $1847-1872, \mathrm{pp}$. [138] to [193].

IV. The solar diurnal variations of declination, horizontal force, and vertical force at Bombay, as derived from the registrations of the Colába magnetographs, PP. [I94] to [235].

V. Influence of height above or below the ground level upon the diurnal variations of declination and horizontal force, pp. [236] to $[24 \mathrm{I}]$.

1 Cf. Vol. I, p. I55, this journal. 
Diurnal variations of declination and of horizontal force for each month (and year) of the years 1865 to I872, deduced from the readings of Grubb's declination magnetometer and of Grubb's horizontal force magnetometer. Appendix to Bombay Magnetical and Meteorological Observations, I884, pp. [I] to [I6].

Appendices to Bombay Magnetical and Meteorological Observations, I886.

I. On the luni-solar variations of magnetic declination and horizontal force at Bombay, and of declination at Trevandrum.

II. Luni-solar variations of magnetic declination at Batavia, and references to later extensions of the investigations of the preceding paper.

III. On the influence of temperature upon the bifilar magnetometer.

IV. Effect of heating the magnetograph room on the scale-coefficient of the vertical force magnetograph.

V. Temperature coefficient of the vertical force magnetograph.

VI. Temperature coefficient of the horizontal force magnetograph. Appendices to Bombay Magnetical and Meteorological Observations, I888- 89 , I vol. $4^{\circ}$.

I. History of the set of magnetographs established at the Colaba Observatory, Bombay.

II. The solar diurnal variations of declination, horizontal force, and vertical force at Bombay, as derived from the registrations of the Colába Magnetographs [continued].

Appendix to Bombay Magnetical and Meteorological Observations, I8go.

The absolute magnetic declination and horizontal force at Bombay, and their secular and annual variations.

Appendix to Bombay Magnetical and Meteorological Observations, I8gI-92, I vol. $4^{\circ}$.

The secular variation of magnetic dip at Bombay during the years I867 to I892.

\section{B.-PAPERS PUBLISHED BY LE,ARNEd SOctETIES.}

On the direct influence of a distant luminary upon the diurnal variations of the magnetic force at the earth's surface. Phil. Mag. March, I858.

On the nature of the sun's magnetic action upon the earth. Proc. Roy. Soc., vol. I2, I862-63, P. 567 .

On the nature of the sun's magnetic action upon the earth. Phil. Trans. R. S., I863, pp. 503-16. Declination disturbances at Bombay, I866. Proc. Roy. Soc., vol. I5, I867, pp. II I-I I4.

On the uneliminated instrumental error in the observations of magnetic dip. Proc. R. S., vol. 17 , I868-69, p. 427 .

On the solar and lunar variations of magnetic declination at Bombay. Part $I$. Proc. Roy. Soc., vol. 17, I869, pp. I6I, I62.

Observations of the absolute direction and intensity of terrestrial magnetism at Bombay. Proc. Roy. Soc., vol. 17,1869 , pp. 426, 427 .

On the lunar variation of magnetic declination at Bombay. Proc. R. S., vol. 20, p. 135, Abstract.

Absolute direction and intensity of the earth's magnetic force at Bombay and its secular and annual variations. Proc. R. S., vol. 20, p. I07, Abstract, Phil. Trans., I876, Pp. 75-90. 
On the lunar variations of magnetic declination at Bombay. Proc. Roy. Soc., vol. 20, I872, pp. I35, I36.

On magnetic induction as affecting observations of the intensity of the horizontal component of the earth's magnetic force. B. A. A. S. Rep., I877, pp. 33,34 .

Sun-spots and terrestrial phenomena. I. On the variation of the daily range of atmospheric temperature, as recorded at the Colaba Observatory, Bombay. II. On the variation of the daily range of the magnetic declination, as recorded at the Colaba Observatory, Bombay. Roy. Soc. Proc., vol. 34, Pp. 23I-264.

Examples of the application of a modified form of Sabine's method of reduction of hourly observations of magnetic declination and horizontal force to a single quarter's registrations of magnetographs at the Colába Observatory, Bombay, to accompany the Second Report of the Committee appointed for the purpose of Considering the best means of Comparing and Reducing Magnetic Observations. Published with the British Association Report for IS86.

Luni-solar variation of the vertical magnetic force at Bombay for the single quarter, November, I875 to January, 1876 , to accompany the Third Report of the Committee appointed for the purpose of Considering the best means of Comparing and Reducing Magnetic Observations. Published with the British Association Report for 1887 .

By $C$. and F. Chambers. On the mathematical expression of observations of complex periodical phenomena, and planetary influence on the earth's magnetism. Phil. Trans., vol. I65, pp. $36 \mathrm{I}-402$.

On the luni-solar vatiations of magnetic declination and horizontal force at Bombay, and of declination at Trevandrum. Proc. Roy. Soc., vol. 40, I886, p. 3 I6.

On the luni-solar variations of magnetic declination and horizontal force at Bombay, and of declination at Trevandrum. Phi.. Trans. Roy. Soc., I887, vol. $178, \mathrm{~A}$. 